IJJM

Ilomata International Journal of Management

P-ISSN: 2714-8971; E-ISSN: 2714-8963

\title{
Implementation of Finger Print Electronic Absental Policy on Discipline and Performance of Civil Servants in The Government Office of Seluma Regency
}

\author{
Dian Setiawan \\ Graduate Program Masters in Management Open University \\ Correspondent: dimdamsetiawan73@gmail.com
}

Submitted : September 19,2020 Revised : October 5, 2020 $\quad$ Published $\quad$ October 30, 2020

\begin{abstract}
Describe the implementation of the fingerprint electronic absence policy on the discipline and performance of civil servants as well as the impact it has on implementing the fingerprint electronic absence policy. Qualitative descriptive method describes various conditions and situations as the object of research. The data collection techniques used were observation, documentation and interviews. After the implementation of fingerprint electronic attendance, discipline increases and obligations as employees have been carried out in accordance with applicable regulations. The application of sanctions in the regional government of seluma regency is in accordance with the regulations of civil servants and the provision of rewards for employees who excel has been carried out properly, to inspire other employees, so that they can work better.
\end{abstract}

Keywords: Fingerprint electronic absence policy implementation.

\section{INTRODUCTION}

In the current era of bureaucratic reform, the central government is required to create a government that is clean, authoritative, free of corruption, collusion and nepotism, as well as elements of government in the regions, be it province or district / city, so as to increase public / community trust in a government that is clean, then improvements are made in the public service sector, starting from the village / sub-district, sub-district, district / city, to provincial level. Civil servants as an extension of the central government in the regions in carrying out their duties are required to understand their main functions and duties as state servants and as public servants. A state servant must also be able to maintain an employee image for the benefit of society and the state. (Wahab, 2005). "Policy implementation can be seen from several perspectives, namely: (1) policy makers, (2) executing officials in the field, and (3) policy targets (target groups)". The main concern of policy makers is focused on "the extent to which the policy has been achieved and what are the reasons for the success or failure of the policy". Policy implementation focuses on "the actions of officials and agencies in the field to achieve program success. (Kurniawati, 2015). Stating that human resources are an important factor in an organization, human resource management is defined as managing and running human resources based on the organization's vision so that goals can be achieved optimally. Thus, what is meant by Human Resource Management is the process of planning, organizing, implementing and controlling human resources in the organization to achieve goals effectively and efficiently. Employee Discipline Violations can occur if there is no awareness and responsibility for the work given by the leadership or superiors of a government agency, so that actions are taken to reduce the violations 
Implementation Of Finger Print Electronic Absental Policy On Discipline And Performance Of Civil Servants In The Government Office Of Seluma Regency

Setiawan

that occur, an examination or interview is carried out in order to find out the background, so that it can be made considerations to be given sanctions or actions by the leadership. Still finding employees / staff who are not disciplined in working in the service office or agency in the Seluma Regency government makes the author interested in examining more deeply. This undisciplined attitude includes arriving late, skipping work, and leaving earlier than the predetermined time. Employees who are late in attending and lazy to come to the office can be a reference in improving public services for the community. The use of absences by using print outs is often abused, for example staff who are late to attend, no hours or evidence of tardiness or who are late in attending are still absent directly without any separate assessment. The use of fingerprint electronic absences (Fingerprint) is expected to make employees more disciplined, attendance time more accurate and known to the leadership.

We cannot avoid technological developments in our daily lives, because technological advances will be balanced with the progress of science. Every new discovery is created to provide positive benefits for human life in order to get something easier, as well as a new way of doing human activities. One of the results of current technological advances is the presence of an electronic fingerprint machine (Fingerprint). With the presence of a fingerprint machine or Fingerprint, of course, it will provide very positive benefits. Lots of companies, institutions, and offices already use fingerprint machines. For government agencies, especially in the field of public services, of course, with the fingerprint tool, there are many benefits that can be obtained. Along with performance and discipline are important aspects that must be possessed by all mankind because with it all human activities become more orderly and directed, especially for employees or employees, so that with the electronic fingerprint attendance machine (fingerprint), the level of discipline to be present is appropriate. time at the office can materialize.

There is still public distrust of the unsatisfactory performance of government in the regions, so the Fingerprint Electronic Attendance system is implemented which is expected to improve employee discipline and performance. In view of these problems, the objectives of this study are: "To describe the implementation of policies. Fingerprint electronic absence and the impact it causes on the discipline and performance of civil servants" (Wahab, 2005).

"Policy implementation can be seen from several points of view, as follows: 1). Policy makers, 2). Implementing officers in the field, and 3). Policy target (target group) ". The main concern of policy makers is to focus on supporting the implementation of these policies both the pros and cons, the extent to which these policies have been achieved, and what causes the success or failure of these policies (Widodo, 2010).

Stated that there are several factors that influence the success or failure of policy implementation, namely: (1). Communication, is the process of providing information about public policies, this needs to be disseminated to actors or policy implementers in order to know what must be prepared to carry out the policy so that the targets will be achieved according to the target, (2). Resources, including human resources, budget resources, equipment resources and authority resources, (3). Disposition, desire or willingness of policy implementers to truly realize what is the common goal and (4). The bureaucratic structure is a dominant institution in the implementation of public policies which has different interests in each hierarchy (Winarno, 2005). The main policy actors must be given sufficient authority to make their own decisions in implementing the policies under their authority (Bungin, 2009). Explaining research using the qualitative descriptive method in the form of a case study, aims to briefly explain the situation, which occurs as it is in the field, to be raised as a problem that must be resolved (Herdiansyah, 
Implementation Of Finger Print Electronic Absental Policy On Discipline And Performance Of Civil Servants In The Government Office Of Seluma Regency

Setiawan

(2015). Qualitative methods are in the form of data in the form of sentences, or narratives from subjects or respondents from research obtained through data collection techniques which are then analyzed and processed using qualitative data analysis techniques that will produce findings or research results will answer the research questions being undertake (Priyodarminto, 1994). in his book the discipline of tips for success, is a condition that is created and formed through a process of a series of behaviors that show the values of obedience, obedience, loyalty, order and / or order. Starting from the description, it can be concluded that the formation of discipline can be done in two ways, namely through the development of personal discipline or the development of discipline that comes from individuals and through the application of strict disciplinary action, meaning that an disciplinary employee will be subject to punishment or sanctions in accordance with error rate.

Civil servant discipline regulations are regulations that regulate obligations, prohibitions and sanctions, if the obligation is not obeyed or the prohibition is violated by civil servants, this is regulated in government regulation number 30, 1980, concerning the disciplinary regulations for civil servants. From a number of disciplinary opinions, important points can be taken into several definitions, as follows: the word discipline can be interpreted as a teaching, practice or a loyal follower, training that develops self-control, character, order and efficiency, obedience, obedience to government regulations and regulations. or ethics, norms and rules that apply in society, punishment which is done through correction and training to achieve controlled behavior (control behavior).

\section{METHODS}

In processing the data in this study, using a qualitative descriptive method in the form of case studies, aims to describe various situations, phenomena of social reality that exist in society as the object of research. The focus of this research is on the presentation of all facts and events in the field in quality regarding the implementation of the fingerprint electronic absence policy and its impact on the discipline and performance of employees in the Seluma district government offices. Determination of interview informants using purposive sumpling (purposive sample), namely the sampling technique used if the researcher has certain considerations in determining the informant (Moleong, 2014). So in this study, the Regional Secretary as the official policy maker, the Head of District, Head of Section, and Head of Subdivision as well as several regional government and OPD staff in Seluma Regency as policy implementers. The research locations that are the object of data collection regarding the implementation of the fingerprint electronic absence policy and its effect on the discipline and performance of civil servants are at the Dinas, OPD and the Seluma regional government secretariat. The data collection techniques in this study used several techniques as follows: 1). Observation is a process of extracting data that is carried out directly by the researchers themselves by making detailed observations of humans as objects of observation and the environment in research (Herdiyansyah, 2015). In this observation the researcher uses objects in the form of photographs as observation data. 2). The interview is a process of communication interaction carried out by at least two people on the basis of availability and in a natural setting, where the direction of the conversation refers to the goals that have been set by prioritizing trust as the main foundation in the process of understanding (Herdiyansyah, 2015). This technique is needed to explore and obtain more in-depth information about the implementation of the fingerprint electronic absence policy and its impact on the discipline and performance of 
Implementation Of Finger Print Electronic Absental Policy On Discipline And Performance Of Civil Servants In The Government Office Of Seluma Regency

Setiawan

employees in local government offices in Seluma district. As a source of information, the researcher took several respondents to be interviewed who were representatives of several OPDs and offices in the Seluma district government as research samples. 3). Documentation of data collection obtained from books, direct and indirect observations, in this study the researchers used documents in the form of regulations of the Regent of Seluma, SK policies on implementing disciplinary rules.

\section{RESULTS AND DISCUSSION}

For the accuracy and validity of the data, the analysis and research results were checked. Data checking is carried out by submitting the results of research data analysis to the head of the department and the head of the field, then the results of research and consultation, either in the form of criticism or further input, are concluded (Moleong, 2014).

At the time of the formation of the New Autonomous Region (New Autonomous Region), the number of Civil Servants in the Seluma Regency Government was only 2,471 people and in 2010 it increased to 3,723 people or increased by 1,252 people and in 2016 increased to 4,164 people, the development or increase of the number of Civil Servants per year can be read in table 1 below.

Table 1.

Development of the number of ASN human resources in the Seluma regency in the last 6 years

\begin{tabular}{llc}
\hline No & Year & Number of PNS (Person) \\
\hline 1 & 2011 & 3.723 \\
\hline 2 & 2012 & 4.055 \\
\hline 3 & 2013 & 4.100 \\
\hline 4 & 2014 & 4.156 \\
\hline 5 & 2015 & 4.185 \\
\hline 6 & 2016 & 4.164 \\
\hline
\end{tabular}

The measurement of the performance of the New Autonomous Region (New Autonomous Region) is based on fiscal performance indicators, namely measuring fiscal dependence, the ability to generate PAD (Regional Original Income), the proportion of capital expenditure to total APBD expenditure, and the contribution of APBD spending (BAPPENAS and UNDP, 2008). Since the establishment of the New Autonomous Region (New Autonomous Region) financial management of Seluma Regency, it has never received the title of WTP (Fair Without Exception) from the BPK (Supreme Audit Agency), the last three years (2013, 2014 and 2015) financial management has received the WDP (Fair With Exception) ) from the CPC. Meanwhile, the PAD contribution to the APBD was 3.62\%, meaning that the regional financial capacity of Seluma Regency was very low and the APBD had a dependency on the Central Government of $96.38 \%$. In addition, the method used to measure the performance of the implementation of the New Autonomous Region (New Autonomous Region) is how the realization and achievement of the local government work program targets contained in the LKPJ, namely the Accountability Statement Report (Regent) to the DPRD and LPPD (Regional Government Accountability Report) to the community. PP No. 6 of 2006, concerning the Performance Report of Government Agencies (LKIP) in carrying out their duties and functions 
Implementation Of Finger Print Electronic Absental Policy On Discipline And Performance Of Civil Servants In The Government Office Of Seluma Regency

Setiawan

as well as executing the budget, has an obligation to report the success or failure of its implementation.

Evaluation of the performance of the Seluma Regency government is carried out every year starting from December 31 to March of the following year or no later than 3 months after the end of the fiscal year. EKPPD (Performance Evaluation of Local Government Administrators) is the result of the elaboration of the Key Performance Indicators (IKK) and translated again into the LPPD (Regional Government Accountability Report) which will become the Regent's Accountability Statement (LKPj).

The results of the evaluation of the performance of the Seluma Regency Government above, based on the 2014 LPPD, obtained the ranking and status of the performance of the third Regional Government of 10 Regencies / Cities with a score of 2.6082 or with the high achievement category. The results of this performance evaluation assessment were validated by the provincial and central teams (Ministry of Home Affairs) (EKPPD Report on LPPD Seluma Regency 2015). Based on EKPPD data, it shows that the administration of the Seluma Regency government gets a satisfactory or "Good" score. Meanwhile, the realization of the program and the achievement of targets based on LKIP (Government Agency Performance Report), the performance of the Seluma Regency Government got a score of 60 with a score of $C$ which was quite good. With the Performance Evaluation of Regional Government Administrators (EKPD), the objective of this is to see the development of the newly developed autonomous regions into districts, especially districts, as well as the commitment of government administrators in the success of development, as a measure of the success of good governance, one of which is Human Resources are they ready. and support for that, so that in its implementation it requires innovation and policies that lead to the strengthening of a good local government system, therefore innovations that need to be applied in improving the performance and discipline of government administrators or employees start with timely attendance at the office, so that there is a sense of responsibility for the workload it carries, for that the application of attendance that runs properly must be properly implemented.

After conducting interviews with several representative employees from several Regional Apparatus Organizations (OPD) in the Seluma Regency Government, the majority agreed to the application of Fingerprint Electronic Attendance, seen from the results of the interview, as follows:

Table 2.

Results of interviews with several civil servants

\begin{tabular}{llcccc}
\hline No & $\begin{array}{l}\text { Implementation of } \\
\text { Fingerprint }\end{array}$ & $\begin{array}{l}\text { Regional } \\
\text { Secretariat of } \\
\text { Local } \\
\text { Government }\end{array}$ & $\begin{array}{l}\text { Regional } \\
\text { Civil Service } \\
\text { Agency }\end{array}$ & $\begin{array}{l}\text { Department Of } \\
\text { Agriculture }\end{array}$ & Total \\
\hline 01 & Agree & 5 & 5 & 5 & 15 \\
\hline 02 & Not Agree & 0 & 0 & 0 & 0 \\
\hline
\end{tabular}

This is because there have been many changes after the implementation of electronic fingerprint attendance, increased discipline and employee performance and responsibility for their main duties are getting better. Based on the above observations, a common thread from this research can be drawn, namely: (1) It is still found that employees of one of the offices in the district government are still lacking in fulfilling the obligations and responsibilities given by their 
Implementation Of Finger Print Electronic Absental Policy On Discipline And Performance Of Civil Servants In The Government Office Of Seluma Regency

Setiawan

leaders, this is due to a lack of awareness of the regulations Yes, then the work is not done on time, and the services provided are not optimal. After the implementation of electronic fingerprint attendance (Fingerprint), employee discipline increases and obligations have been carried out in accordance with their responsibilities, where the employee or staff can complete their work in accordance with the time that has been determined based on their respective positions or authorities, does not make it difficult for those who served. (2) The application of sanctions / punishments in district government agencies / institutions is always in accordance with regulations and also rewards for employees who excel have been properly implemented, in order to be used as inspiration and to spur enthusiasm for other employees, so that they can achieve and work. even better.

\section{CONCLUSION}

The implementation of the fingerprint electronic attendance policy at district government offices only has an impact on employee discipline and performance, innovation in the field of electronic attendance provides motivation for employees to commit to improving their discipline which has an effect on improving performance, and the public services provided the more optimal. Can manage time and commitment to main duties and functions as a public servant.

The application of fingerprint electronic attendance (fingerprint) can be used as a solution in improving the discipline and performance of employees or employees in government agencies, thus the sanctions are given as a form of controlling employees who do not heed the regulations and are not in accordance with their main duties and functions as servants. Society, also as a form of shock therapy for employees who are still lazy at work and less productive.

If a red thread is drawn before and after the application of fingerprint electronic attendance (fingerprint), then there are several things that support this change, namely as follows: (1) policy maker; (2) implementing policies; (3) good governance; (4) the level of community satisfaction; and (5) giving rewards and punishments.

Based on the results of the analysis of the facts obtained, the authors recommend, as follows:

1. The application of fingerprint electronic attendance (fingerprint) can be a solution in improving employee discipline and performance, so that its use is realized in offices, agencies, OPDs, especially in local government circles, in order to change the habit of undisciplined attendance at the office, by arriving late and coming home ahead of the predetermined hours. With the use of fingerprint electronic attendance (fingerprint) it is hoped that employees can make the best use of their time, so that employees are able to work effectively, efficiently and in accordance with their main duties and functions as public servants.

2. In order for the leadership's inherent supervision to be carried out on an ongoing basis, that is to carry out regular performance evaluations, either once a month or once every three months, by involving the lowest-level leaders starting from the head, head of subdivision, head, head, and secretary, so that the leadership can find out discipline, performance and achievement of the staff / employees, so that the emotional relationship between leaders and subordinates can be well established.

3. Leaders give rewards to employees / staff who perform well and give punishment to employees / staff who work not in accordance with regulations or are lazy. 
Implementation Of Finger Print Electronic Absental Policy On Discipline And Performance Of Civil Servants In The Government Office Of Seluma Regency

Setiawan

4. The electronic fingerprint attendance policy (fingerprint) and the disciplinary rules for civil servants should continue to be disseminated to all employees in the district government so that they will know more about the obligations and restrictions on employees and the sanctions they will receive if they violate these rules.

\section{REFERENCES}

Bungin. (2009). Qualitative Research. Jakarta. Kecana Jakarta.

Herdiansyah, H. (2015). Interviews and Observations, as Qualitative Data Extraction Instruments, Jakarta. PT. RajaGrafindo Persada.

Herdiansyah, H. (2014). Qualitative Research Methodology for Social Sciences, Jakarta., Salemba Humanika.

Kurniawati. (2015). Human Resource Development. South Tangerang. Open University.

Masril. (2019). Implementation of Civil Servant Discipline Policy at the South Totikum District Office, Banggai Islands Regency. e Journalist Journal, Volume 4 (1), 156-16.

Maulana, A. (2016). Strategic Management. South Tangerang. Open University.

Mils. (2003). Observations are not only made on objects of human behavior, but on the system.

Moleong. (2014). purposive sumpling (purposive sampling) the sampling technique used if the researcher has certain considerations in determining informants.

Nurcholis. (2007). Theory and Practice of Regional Autonomy Government. Jakarta. P.T. Gramedia Widiasarana Indonesia.

Prijodarminto. (1994). Discipline Tips for Success. Bandung. Pradnya Paramita.

Government regulations. No. 53. (2010). About Civil Servant Discipline. Article 3,4,7.

Riant, N.D. (2006). Public Policy For Developing Countries. Jakarta. PT.Elex Media Komputindo.

Setya., et al. (2018). Implementation of Discipline Policies for Civil Servants (A Study at the Human Resources and Human Resources Development Agency in Talaud Islands Regency). Journal of Governmental Science Department. Samratulagi University Volume $2(2)$.

Sobirin. (2015). Work management. South Tangerang. Open University.

Sugiyono. (2005). Administrative Research Methods. Bandung. PT. Alphabeta.

Situmorang, V. M. \& Juhir. J. (1994). Legal Aspects of Inherent Supervision in Government Officials. Jakarta. PT.Rineka Cipta

Wahab. (2005). Policy implementation can be viewed from several points of view.

Widodo. (2010). Factors that influence the success or failure of policy implementation.

Winarno. (2005). The bureaucratic structure of the dominant institution in the implementation of public policies has different interests in each hierarchy. 